\title{
The effect of inflation, profit-loss sharing loan, and capital adequacy towards performance of Indonesian Islamic banks
}

\author{
Luksi Visita1 \\ ${ }^{1}$ Management Department, Faculty of Islamic Economics and Business, UIN Walisongo Semarang, Indonesia
}

Abstract
The purpose of this study is to observe the impact of inflation, profit-loss sharing loan, and capital adequacy towards performance of Islamic banks in Indonesia. This study utilizes longitudinal study from 2010 to 2018 towards Islamic Commercial Banks and Sharia Business Units that are listed in Otoritas Jasa Keuangan/OJK (Financial Service Authority) of Indonesia. Using pool-time series data, the variables studied are inflation, capital adequacy ratio (CAR), profit-loss sharing loan, and return on assets (ROA). The result shows that only inflation has no significant effect on performance. Capital adequacy affects positively significant, while profit-loss sharing loan affects negatively significant. This study add new perspective on how macroeconomic variable influence Islamic banks' performance in Indonesia. Additionally, this study is also distinctive because of lengthier observation period (eight years) compared to other studies in recent five years.

\section{INTRODUCTION}

The study of Islamic bank profitability has been ongoing since fifteen years ago. Fifteen years ago, Bashir (2003) and Haron (2004) provide conceptual and empirical model of factors affecting Islamic banks' profitability. They gave two fundamental side of factors, internal factors (banks' spesific characteristics) and external factors (macroeconomic conditions) as the possible predictor of Islamic banks' profitability. Since then, the study of Islamic banks profitability has developed into various type of research.

From all those studies, Indonesia become one of the subject of study for its large population of moslems and its effort to develop Islamic banking sector. However, from the latest five years, the study of Islamic bank profitability in Indonesia mainly focus on internal characteristics. Moreover, from the latest five years, researchers examine Islamic banks with time range less than eight years. Wibowo and Syaichu (2013) studied three
Islamic commercial banks from 2008 to 2011. Sahara and Yanita (2013) studied thirteen Islamic banks from 2008 to 2010. Zulifiah and Susilowibowo (2014) studied three major Islamic banks from 2008 to 2012.

By adopting Bashir (2004) and Haron (2003) conceptual study, this paper implicates inflation as one of the macroeconomic factor to predict Islamic banks' profitability in Indonesia. This effort is in line with suggestion of Samad (2015) to invlove inflation in determining profitability of Islamic banks. The effort to invlove macroeconomic factor is also anticipated in order to fulfill the claim that Islamic bankings are dependant towards the macro economy of a country (Bashir, 2004).

Specifically, this paper examines the impact of inflation, loss-profit sharing financing, and capital adequacy as the determinants of Islamic banks profitability. The result is projected to give further information about the role of macroeconomic factors in shaping Islamic banks in Indonesia. 


\section{LITERATURE REVIEW AND HYPOTHESES DEVELOPMENT}

\section{Islamic banks' profitability in Middle East and Asia}

Most Islamic banks studies were conducted in Middle East area, some part of Asia, and Africa. In Middle East area, liquidity becomes prominent for Islamic banks' profitability. Almazari (2014) contrasted the internal factors of bank profitability between Saudi Arabia and Jordan. He found that liquidity ratio and equity affect positively performance both in Saudi Arabia and Jordan, while cost income ratio and bank size affect negatively performance. In Africa, study by Karim, Sami, and Hichem (2010) found that capital and size are important to determine Islamic banks' profitability, while economic growth and inflation promote profitability.

Another study in Middle East Area was conducted by Mokni and Rachdi (2014). They found that non performing loan and offbalance sheet activities affect negatively Islamic banks' profitability, while liquidity and ownership affect positively. Meanwhile Zarrouk, Jedidia, and Moualhi (2016) analyze factors affecting Islamic bank profitability and found that Islamic banks' profitability is affected by non financing activity help Islamic bank get higher profits, and when the GDP and investment rate are high. Research in Asian region such as in Pakistan as conducted by Tariq, Usman, Mir, Aman, and Ali (2014) shows that capital and bank size affect profitability positively, meanwhile inflation affect negatively.

In a broader context, Masood and Ashraf (2012) studied the influence of nine internal specific variables and two macroeconomic variables mainly economic growth rate and inflation rate. They found that asset size, capital adequacy, loans to asset, and assets management are impacting Islamic banks' profitability positively. They also noted that Islamic banks tend to have higher risks than conventional banks. However it is important to note that the study was conducted in eleven different country and each country is represented by one up to two Islamic banks only.

\section{Islamic banks' profitability in Indonesia}

The recent studies of Islamic banks' profitability in Indonesia were focused on the specific internal aspect of the banks. Abusharbeh (2014) found that equity financing has positive significant relationship with NPF. Debt financing (murabahah) was also found to have significant relationship with future earnings in Indonesian Islamic banks. Purbaningsih (2014) found that liquidity to total asset, financial to debt ratio (FDR), and non-performing financial rate (NPF) simultaneously affect profitability but when it tested independently, only liquidity to deposit that has significant effect (negatively). Sriyana (2015) found that net profit margin, and FDR are significantly affect performance. Meanwhile NPF and operating efficiency have negative affect towards profitability. The recent study was conducted by Abdillah, Hosen, and Muhari (2016) who found that liquidity influence ROA negatively while CAR positively.

The study of Islamic banks' specific internal character has been done by several researchers in the last six years, however, there was a limited discussion on the role of macroeconomics for banks in general, and Islamic banks, purposely, in Indonesia. Furthermore, there were quite a few studies which demonstrated mixed results when it comes to the macroeconomic factors and its link with Islamic banks' performance. Tariq et al (2014) found that inflation affect Islamic banking negatively, meanwhile Karim et al (2010) found the other way round. The urgency to involve macroeconomic variable is even more prominent because developing country is susceptible to banking crisis (Demirgüç-Kunt \& Detragiache, 1998).

To this date, inflation is associated with the potential of the escalation of interest. Additionally, inflation could signal a mishandling of a country's macroeconomy (Demirgüç-Kunt \& Detragiache, 1998). It turns out that inflation is not always affecting a country negatively. In some cases, inflation has a role in reducing unemployment (Mankiw, 2006).

\section{Relationship between inflation, capital adequacy, and profit-loss sharing loan}

Bashir (2003) emphasized that inflation has a potential to affect an Islamic bank negatively if the overhead cost of the Islamic bank is bigger than the inflation rate. This postulation is comparable with Duraj and Mocis' (2015) in a context of conventional banking. To examine inflation role, this study utilize 
framework of Boyd and Champ (2006) who rationalized that inflation could affect banks' instrument such as money market, treasury bills, and deposit.

In the context of Islamic banking, inflation has the capacity to rise displacement from Islamic bank to conventional bank (Saekhu, 2015). This means that customers prefer investing in conventional banks, since during inflation the interest of conventional banks rises. With the depleted interest of customers to invest in Islamic bank, this will hampher Islamic banks' effort to gain profit. At the end of the day, low profit have bigger possibility to lead Islamic bank to poor performance. Based on the justification above, author offer this hypothesis:

\section{H1: Inflation affects performance of Islamic banks negatively}

There are several studies in recent five years which support the assumption that capital adequacy affecting performance. Jaffar and Manarvi (2011) found that Islamic banks with capital adequacy performs well. The same finding also found by Widyaningrum and Septiarini (2015) and Rahmi and Anggraini (2013) who study performance of Islamic banks in Indonesia. Olalekan and Adeyinka (2013) who study performance of Nigerian banks also found that capital adequacy is vital for bank performance. Rafelia and Ardiyanto (2013) found that capital adequacy is important for ROE of Islamic banks.

Capital adequacy has been a vital variable for bank because high capital adequacy, indicates a high discretion in managing its fund for the sake of profitable activities (Wibowo and Syaichu, 2013). The urgency of capital adequacy is even higher for Islamic banks, because Islamic banks bear higher risk compared to conventional bank (Hussain \& Al-Ajmi, 2012). An adequate capital could help bank to grow deposit and loan (Karim, Hassan, Hassan, \& Mohamad, 2014). As a result, bank could gain more business, therefore get more possibility to gain profitability. Based on the explanation above, the hypothesis is:

\section{H2: Capital adequacy affects Islamic banks' performance positively}

In general, conventional banks and Islamic banks rely on loan instrument as one of the source of income. The higher loan that is given by the bank, the higher possibility of the bank to gain more profit (Febianto, 2012). The same sense could be apply in understanding loan in Islamic banks. However, unlike conventional bank who utilize interest to get profit in lending activity, Islamic banks utilize the principle of profitloss sharing.

Profit-loss sharing loan is the identity of Islamic banks. Profit-loss sharing scheme is known bring moral attribute since it's able to distribute risk fairer compared with interestbased credit (Sugema, Bakhtiar, and Effendi, 2010). Profit-loss sharing credit is also more profitable in a long run (Hasan, 1985). Abdalla Ahmed (2008) argued that profit-loss sharing is more profitable towards the bank since there is small to zero collateral need to be provided by the entrepreneur. This resulted as the profit-loss sharing mechanism is more favorable for financing in the perspective of the entrepreneur. A profit-loss sharing loan combined with good macroeconomics condition, will enable Islamic bank to get profit (Bashir, 2003), and therefore better performance. Based on this reason, the auhtor offers this hypothesis:

H3: Profit-loss sharing loan affects Islamic banks' performance positively

\section{METHODS}

This study examine Islamic commercial banks and Sharia Business Unit of conventional banks which are listed in the statistic report of Otoritas Jasa Keuangan, OJK (Financial Service Authority Board; FSAB) of Indonesia. In total, there are 14 Islamic commercial banks and 20 Sharia business unit in Indonesia, per 2018. The design of this study is a longitudinal research with time series-pool data. Total observation collected is 108 observations. The data is collected through database provided by OJK/FSAB of Indonesia from 2010 to 2018.

The operationalization of variabel will be adapted from Bashir (2003). Inflation will be proxied by monthly annual inflation rate. Capital adequacy will be proxied by capital adequacy ratio (CAR), profit-loss sharing loan will be proxied by profit-loss sharing loans given by Islamic banks to customers (for example mudharaba and musharaka contracts). The last variable, performance, is proxied by return on asset (ROA). 
This research utilize the classical assumption test to examine the validity of the data, especially multicollinearity test, autocorrelation test, heteroscedasticity test, and normality test. Although the initial data contain autocorrelation problem, after transforming the initial model to difference model (Ghozali, 2018), the data fulfill the classical assumption test. Table 1 contains result of collinearity statistics which shows that all variables has less than 10 Variance Inflation Factor (VIF) and more than 0,1 Tolerance score which indicates that there is no multicollinearity problem. From the autocorrelation hypothesis testing, the data fulfill the absence of autocorrelation problem (DW score = 1,806; Table 2).

Table 1.

Result of multicollinearity test and autocorrelation test

\begin{tabular}{lll}
\hline Variables & \multicolumn{2}{l}{$\begin{array}{l}\text { Collinearity } \\
\text { Statistics }\end{array}$} \\
\cline { 2 - 3 } & Tolerance & VIF \\
\hline $\begin{array}{l}\text { Profit-loss sharing Ioan } \\
\text { (PLSL) }\end{array}$ & 0.294 & 3.404 \\
\hline Inflation (INF) & 0.929 & 1.077 \\
\hline Capital adequacy (CAR) & 0.286 & 3.491 \\
\hline
\end{tabular}

Normal P-P Plot of Regression Standardized Residual Dependent Variable: Lag_ROA2

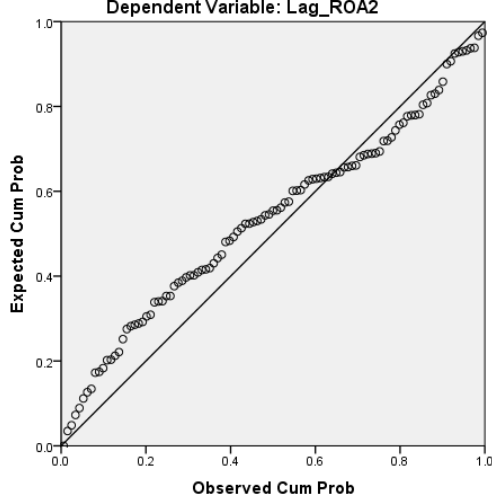

Figure 1.

Normal P -P Plot of Regression Standardized Residual

Figure 1 shows Scatterplot of dependent variable and its residuals. From the Scatterplot figure, it can be seen that the dots are spread randomly above and below 0 in the $Y$ axis. This indicates that there is no heteroscedasticity problem (Ghozali, 2018). The author overlook the normality test since large sample (108 observations) should not cause major normality problems and therefore the distribution of the data can be ignored (Pallant, 2007, Elliot \& Woodward, 2007, and Atman \& Bland, 1995 in Ghasemi and Zahediasl, 2012).

\section{RESULTS AND DISCUSSION}

The $\mathrm{R}$ Square result is 0.736 which indicates that the model used in this research could explain 73.6 percent of the outcome variable (ROA). ANOVA result shows that all variables simulteneously affect performance (F score= 96.760; Sig/Prob= 0.000) (Table 2).

Figure 1 shows Scatterplot of dependent variable and its residuals. From the Scatterplot figure, it can be seen that the dots are spread randomly above and below 0 in the $Y$ axis. This indicates that there is no heteroscedasticity problem (Ghozali, 2018). The author overlook the normality test since large sample (108 observations) should not cause major normality problems and therefore the distribution of the data can be ignored (Pallant, 2007, Elliot \& Woodward, 2007, and Atman \& Bland, 1995 in Ghasemi and Zahediasl, 2012).

Table 2.

Result of ANOVA and descriptive statistic

\begin{tabular}{llll}
\hline R-squared & $\mathbf{0 . 7 3 6}$ & $\begin{array}{l}\text { Mean } \\
\text { depedent var }\end{array}$ & $\mathbf{0 . 4 5 7}$ \\
\hline $\begin{array}{l}\text { Adjusted R- } \\
\text { squared }\end{array}$ & 0.729 & $\begin{array}{l}\text { S.D dependent } \\
\text { var }\end{array}$ & 0.225 \\
\hline $\begin{array}{l}\text { S.E of } \\
\text { regression }\end{array}$ & 0.30 & F-stat & 96.76 \\
\hline DW stat & 1.806 & Prob (F-stat) & 0.000 \\
\hline
\end{tabular}

When tested individually, the result shows that capital adequacy (CAR) and profit-loss sharing loan (PLSL) affect performance (ROA) significantly, meanwhile inflation (INF) is not affecting ROA significantly (Table 3 ). Hence, Hypothesis $1(\mathrm{H} 1)$ is not supported.

Further from Table 3, the coefficient of CAR is 1.329 which indicates that capital adequacy is affecting performance positively. Hence, the Hypothesis $2(\mathrm{H} 2)$ is supported.

At last, the coefficient of PLSL is -0.651 which indicates that profit-loss sharing loan is affecting performance negatively. Hence the Hypothesis $3(\mathrm{H} 3)$ is partially supported. 
Table 3.

Result of Regression

\begin{tabular}{lllll}
\hline Variable & $\begin{array}{l}\text { Coeffic } \\
\text { ient }\end{array}$ & S.E & t-Stat & Sig \\
\hline PLSL & -0.651 & 0.000 & -.7 .006 & 0.000 \\
\hline INF & 0.000 & 0.399 & -0.003 & 0.998 \\
\hline CAR & 1.329 & 0.009 & 14.127 & 0.000 \\
\hline
\end{tabular}

Profit-loss sharing loan is found to be a significant factor that influence performance negatively. This negative cause could be understood because Islamic banks' bear higher risks (Khan \& Ahmed, 2001; Sundararajan \& Errico, 2002). The higher risks a bank bear, the higher the financial burden, and therefore, it could jeopardize the performance.

Inflation is found to be not a significat factor that influence the performance of Islamic banks. This finding is in line with Swandayani and Kusumaningtias (2012) who reasoned that the cause of non significant result is mainly because society thinks that Islamic banking is more profitable and more secure during high inflation.

Although Swandayani and Kusumaningtias (2012) thought that society's perception of profitability and security, the author has different reasoning. Inflation naturally will cause higher raise of banks' interest (Mankiw, 2006). In a conventional bank, this high interest rates perhaps could attract customers more because there is a higher possibility of return rate. However, Islamic banks do not refer and do not depend on interest rate for their profit-loss sharing contracts. In profit-loss sharing contracts utilized by Islamic banks, the nisbah or profit sharing ratio is determined independently between bank and customers. Some of the factors that determine profit-loss sharing are profit-loss sharing income and cost, and Islamic banks' accounting policy (Susana \& Prasetyanti, 2011).

Capital adequacy is found to be positively significant towards performance. This finding is in line with Amelia (2015), Anggreni \& Suardhika (2014), and Akhtar, Ali, and Sadaqat (2011) who also found that capital is vital for Islamic banks. It is foresaw that capital is imperative for Islamic banks of Indonesia because majority of them are private banks. Furthermore, the capital adequacy is act as a protection for Islamic banks who bear higher risks compared with conventional banks.

\section{CONCLUSION}

The majority of Islamic banks studies in Indonesia are dominated by role of banks' specific internal characters. This study tries to involve macroeconomic conditions as one of determinant of Islamic banks' performance.

Most of the time inflation is claimed to be the one who responsible as loss of a company or bring threats towards corporation. The finding in this study add empirical prove of how inflation is statistically trivial towards Islamic banks. This finding also complements the study of Islamic banks performance in Indonesia. Through this study, the empirical test of capital adequacy and profit-loss sharing is performed.

Although the study utilizes inflation as the external determinant, there is limitation of study. Inflation seems not enough in grasping the whole macroeconomic factor and its effect on Islamic banks. Future study should try to investigate various macroeconomic factors, such as poverty rate, income rate, foreign debt, or economic growth. Future study also could investigate the mixed effects of inflation towards Islamic banks. In order to get better understanding between inflation and Islamic banks' performance, examining the role of operational expenses is recommended (Bashir, 2003).

\section{REFERENCES}

Abdalla Ahmed, G. (2008). The implication of using profit and loss sharing modes of finance in the banking system, with a particular reference to equity participation (partnership) method in Sudan. Humanomics, 24(3), 182-206.

Abdillah, R., Hosen, M. N., \& Muhari, S. (2016). The determinants factor of Islamic bank's profitability and liquidity in indonesia. Knowledge Horizons. Economics, 8(2), 140.

Abusharbeh, M. T. (2014). Credit risks and profitability of Islamic banks: Evidence from Indonesia. World Review of Business Research, 4(3), 136-147.

Akhtar, M. F., Ali, K., \& Sadaqat, S. (2011). Factors influencing the profitability of Islamic banks of Pakistan. International Research Journal of Finance and Economics, 66(66), 1-8. 
Almazari, A. A. (2014). Impact of internal factors on bank profitability: Comparative study between Saudi Arabia and Jordan. Journal of Applied finance and banking, 4(1), 125.

Amelia, E. (2015). Financial Ratio and Its Influence to Profitability in Islamic Banks. Al-latishad: Jurnal IImu Ekonomi Syariah, 7(2), 229-240.

Anggreni, M. R., \& Suardhika, M. S. (2014). Pengaruh Dana Pihak Ketiga, Kecukupan Modal, Risiko Kredit Dan Suku Bunga Kredit Terhadap Profitabilitas Bank BUMN Tahun 20102012. E-Jurnal Akuntansi, 27-37.

Bashir, A. H. M. (2003). Determinants of profitability in Islamic banks: Some evidence from the Middle East. Islamic economic studies, 11(1).

Ben Selma Mokni, R., \& Rachdi, H. (2014). Assessing the bank profitability in the MENA region: A comparative analysis between conventional and Islamic bank. International Journal of Islamic and Middle Eastern Finance and Management, 7(3), 305-332.

Boyd, J. H., \& Champ, B. (2006). Inflation, banking, and economic growth. Federal Reserve Bank of Cleveland, 1-4.

Demirgüç-Kunt, A., \& Detragiache, E. (1998). The determinants of banking crises in developing and developed countries. Staff Papers, 45(1), 81-109.

Febianto, I. (2012). Adapting risk management for profit and loss sharing financing of Islamic banks. Modern Economy, 3(01), 73.

Ghasemi, A., \& Zahediasl, S. (2012). Normality tests for statistical analysis: a guide for nonstatisticians. International journal of endocrinology and metabolism, 10(2), 486.

Ghozali, I. (2018). Aplikasi Analisis Multivariate dengan Program IBM SPSS

(edisikesembilan). Semarang:

Universitas Diponogor

Haron, S. (2004). Determinants of Islamic bank profitability. Global Journal of Finance and Economics, 1(1), 11-33.
Hasan, Z. (1985). Determination of profit and loss sharing ratios in interest-free business finance. Journal of King Abdulaziz University: Islamic Economics, 3(1).

Karim, B. K., Mohamed Sami, B. A., \& Hichem, B. K. (2010). Bank-specific, industry-specific and macroeconomic determinants of African Islamic banks' profitability. International Journal of Business and Management Science, 3(1), 39.

Khan, T., \& Ahmed, H. (2001). Risk management: an analysis of issues in Islamic financial industry. Islamic Development Bank, Islamic Research and Training Institute.

Mankiw, N.G. (2006). Principles of macroeconomics. Cengage Learning.Duraj Mocis 2015 inflation, conventional bank

Masood, O., \& Ashraf, M. (2012). Bankspecific and macroeconomic profitability determinants of Islamic banks: The case of different countries. Qualitative Research in Financial Markets, 4(2/3), 255-268.

Purbaningsih, Y. P. (2014). The effect of liquidity risk and non performing financing (NPF) ratio to commercial Sharia bank profitability in Indonesia. International Proceedings of Economics Development and Research, 73(5).

Sahara, Y., \& Yanita, A. (2013). Analisis pengaruh inflasi, suku bunga $\mathrm{BI}$, dan produk domestik bruto terhadap return on asset (ROA) bank syariah di Indonesia. Jurnal IImu Manajemen (JIM), 1(1).

Saekhu, S. (2015). Pengaruh Inflasi terhadap Kinerja Pembiayaan Bank Syariah, Volume Pasar Uang Antar Bank Syariah, dan Posisi Outstanding Sertifikat Wadiah Bank Indonesia. Economica: Jurnal Ekonomi Islam, 6(1), 103-128.

Samad, A. (2015). Determinants bank profitability: Empirical evidence from Bangladesh commercial banks. International journal of financial research, 6(3), 173-179. 
Sriyana, J. (2015). Islamic banks' profitability amid the competitive financing in Indonesia. International Journal of Applied Business and Economic Research, 13(4), 1695-1710.

Sugema, I., Bakhtiar, T., \& Effendi, J. (2010). Interest versus profit-loss sharing credit contract: Effciency and welfare implications. International Research Journal of Finance and Economics, 45(1), 58-67.

Sundararajan, V., \& Errico, L. (2002). Islamic financial institutions and products in the global financial system: Key issues in risk management and challenges ahead (Vol. 2). International Monetary Fund.

Susana, E., \& Prasetyanti, A. (2011). Pelaksanaan dan Sistem Bagi Hasil Pembiayaan Al-Mudharabah pada Bank Syariah. Jurnal keuangan dan Perbankan, 15(3).

Swandayani, D. M., \& Kusumaningtias, R. (2012). Pengaruh inflasi, suku bunga, nilai tukar valas dan jumlah uang beredar terhadap profitabilitas pada perbankan syariah di Indonesia periode 2005-2009. AKRUAL: Jurnal Akuntansi, 3(2), 147-166.

Tariq, W., Usman, M., Mir, H. Z., Aman, I., \& Ali, I. (2014). Determinants of commercial banks profitability: Empirical evidence from Pakistan. International Journal of Accounting and Financial Reporting, 4(2), 1-22.

Zarrouk, H., Ben Jedidia, K., \& Moualhi, M. (2016). Is Islamic bank profitability driven by same forces as conventional banks?. International Journal of Islamic and Middle Eastern Finance and Management, 9(1), 46-66.

Zulifiah, F. (2014). Pengaruh inflasi, bi rate, capital adequacy ratio (car), non performing finance (npf), biaya operasional danpendapatan operasional (bopo) terhadap profitabilitas bank umum syariahperiode 2008-2012. Jurnal IImu Manajemen (JIM), 2(3). 